\title{
GLOBALIZATION VS INTERNATIONALIZATION FOR ENTREPRENEURS
}

\author{
Bambang Pratama \\ Jurusan Manajemen, Fakultas Ekonomi dan Bisnis, Bina Nusantara University \\ Jln. K.H. Syahdan No. 9, Kemanggisan, Palmerah, Jakarta Barat 11480
}

\begin{abstract}
In an article in the Harvard Business Review Theodore Levitt published The Globalization of Markets. Business activities across the country after it became a very interesting topic of study for both academics and practitioners. This topic has become so phenomenal because his arguments about globalization is the economic convergence with business activities without any national barriers. In contrast to the internationalization that tends to narrow and tends to do business across national borders. Central idea must answered by manager and entrepreneurs is whether your market global or international. Before answering them it requires understanding and a new paradigm on this matter. Furthermore, Thomas Friedman in his book "The world is flat" also reinforces Levitt idea and prescript a world with evolution of information and technology. This new economic eras opened new opportunity on entrepreneur point of view. There is wide open door to enter global market and more easy to accelerate company growth or new business start-up.
\end{abstract}

Keywords: business, globalization, internationalization, market, entrepreneur, manager

\begin{abstract}
ABSTRAK
Di sebuah artikel pada Harvard Business Review, Theodore Levitt mempublikasikan tulisan berjudul Globalization of Markets; sebuah review aktivitas bisnis setelah menjadi sebuah topik menarik untuk akademisi dan praktisi. Topik ini juga menjadi fenomena karena argumen beliau tentang globalisasi yang merupakan sebuah konvergensi ekonomi dengan aktivitas bisnis tanpa adanya hambatan nasional. Hal tersebut kontras dengan internasionalisasi yang cenderung lebih menyempit dan berhubungan bisnis dengan bagian luar perbatasan nasional. Ide sentral yang harus dijawab oleh manajer dan para entrepreneur adalah apakah pasar mereka global atau internasional. Sebelum menjawabnya, mereka butuh pengertian dan paradigma baru tentang hal ini. Lebih lanjut, Thomas Friedman dalam bukunya 'The World is Flat' juga memperkuat ide Levitt dan menuliskan sebuah dunia dengan evolusi informasi dan teknologi. Era baru ekonomi ini membuka kesempatan baru dalam sudut pandang entrepreneur. Ada sebuah pintu yang terbuka lebar untuk memasuki pasar global dan lebih mudah untuk menyesuaikan perkembangan perusahaan atau bisnis baru.
\end{abstract}

Kata kunci: bisnis, globalisasi, internasionalisasi, pasar, entrepreneur, manajer 


\section{PENDAHULUAN}

Sebuah impian terhadap dunia tanpa batas (borderless) telah menjadi kenyataan saat ini, berbagai percepatan informasi menjadi evolusi peradaban dunia baru dalam sejarah manusia. Terbuka lebarnya peluang dalam menjelajah dunia dalam hitungan detik telah menjadi pemandangan seharihari saat ini. Keterbukaan informasi global ini, telah membentuk masyarakat dunia menjadi otonom dan lebih mandiri. Dunia tanpa batas telah membuka sekat-sekat batas negara yang selama ini menjadi penghalang, berbagai peluang baru bermunculan khususnya bagi seorang entrepreneur, dengan menitikberatkan pada inovasi dan kreativitas, globalisasi menjadi sebuah jalan bebas hambatan dalam menjelajah dunia baru.

Secara harfiah globalisasi (borderless) dapat diartikan sebagai satu kesatuan planeter sehingga terciptanya kemudahan interaksi satu sama lain di berbagai belahan bumi ini, kenyataannya dalam konteks ekonomi hal ini belum terjadi masih terdapat hambatan regional dari beberapa perkumpulan negara baik di Asia, Eropa maupun Amerika. Globalisasi bagi pengembangan usaha secara aksiologis memiliki banyak keuntungan, disamping kecepatan waktu juga akses informasi yang akan didapat. Perbedaan jaman ini dapat menyebabkan pengembangan usaha untuk mengglobal menjadi lebih cepat dari sebelumnya, bergantung pada inovasi dan keunikan apa yang ditawarkan dalam menjawab kebutuhan orang.

Peluang baru ini dapat dimanfaatkan oleh entrepreneur, baik dalam membuat sebuah usaha baru yang inovatif, maupun untuk mengembangkan usaha menjadi mendunia. Dukungan ilmu pengetahuan khususnya teknologi informasi telah mengantarkan berbagai fenomena baru di dunia, hingga akhirnya bermunculan berbagai ide kreatif dan inovatif berbasis IT. Ini sesuai dengan ramalan Marx dalam Cline (n.d.) bahwa ekonomi yang ideal memerlukan pertukaran yang seimbang. Terbentuknya man to man competition bukan lagi sebuah khayalan, saat ini telah menjadi tantangan yang harus dijawab oleh para generasi Y.

Stephen King, seperti dikutip oleh Kardoyo (2008), pada pembukaan acara di Fakultas Bisnis, Ekonomi dan Hukum, Universitas Quinsland generasi Y adalah mahasiswa yang lair antara 1982 sampai 1994, pada generasi ini mereka: mengerti teknologi dan perubahan-perubahannya; mereka memiliki keprihatinan terhadap isu-isu sosial lingkungan dan kemiskinan; mereka percaya bahwa ada batasan antara hidup dan bekerja. King juga mengatakan bahwa generasi millennium ini memiliki tantangan untuk menjawab tantangan terhadap bisnis yang tradisional menuju inovatif dan berbasis ICT.

\section{PEMBAHASAN}

\section{Ide tentang Globalisasi}

Ide globalisasi pasar tidak mengagetkan, dalam jangka waktu yang cukup panjang para pemikir berusaha untuk memikirkan dunia sebagai satu unit dari pada percampuran negara-negara dan konsumen. Konflik bersenjata yang dianggap pertama kali membawa efek kuat pada tahun 1914 dan 1918. Menimbulkan sebuah kesadaran terhadap dampak radioaktif dari senjata nuklir yangakan menimbulkan konsekwensi global, pada tahun 1963 dan menimbulkan perspektif secara global terhadap lingkungan dunia pada tahun 1970. Selain itu persaingan dua negara adikuasa Amerika Serikat dan Uni Soviet terhadap ruang angkasa yang dimulai dengan proyek sputnik di Soviet pada tahun 1957 dan klimaksnya pada saat manusia pertama kali mendarat di bulan pada tahun 1969 telah membawa paradigma, Kuhn (1970) baru pada perspektif baru tentang pesawar ulang alik. 
Terdapat dua cara dalam memahami globalisasi, pertama sebagai trend dan sebagai heuristika, kebanyakan orang tidak dapat membedakan keduanya. Cara pertama dalam memandang globalisasi adalah sebagai proses aktualisasi integrasi ekonomi. Akselesari dan alur pikir barang dan keuangan, dapat juga yang lainnya. Dalam artian mungkin tidak ada satu proses globalisasi tetapi adanya kemungkinan terhubungnya proses globalisasi yang menimbulkan pertanyaan baru, yaitu globalisasi apa? kita mendengar dan membaca globalisasi keuangan, perdagangan, kebijakan, budaya, hampir semuanya. Hal ini dimungkinkan sebagai perpektif umum masyarakat terhadap globalisasi.

Konsepsi awal terhadap globalisasi adalah sebagai evolusi perubahan trend dunia, secara inheren mewariskan perdebatan, karena para penentang dan pemimpin menyarankan bahwa integrasi ekonomi seharusnya dapat kita lihat berbad-abad sebelumnya. Pertanyaan ekonomi tentang globalisasi berimplikasi pada perbedaan kontra fakta bahwa integrasi pasar untuk barang dan dana adalah telah terjadi, dan faktanya membawa pertanyaan pada pertanyaan tidak hanya ukuran besarnya, tetapi perbedaan harga pada pasar nasional. Ini juga menimbulkan perdebatan hingga tidak menunjukan adanya integrasi eknomi.

\section{Theodore Levitt “The Globalization of Market”}

Borong (n.d.) menjabarkan tentang istilah globalisasi pertama kali digunakan oleh Theodore Levitt pada tahun 1985 yang menunjuk pada politik ekonomi, khususnya politik perdagangan bebas dan transaksi keuangan. Menurut sejarahnya, akar munculnya globalisasi adalah revolusi elektronik dan disintegrasi negara-negara komunis. Revoluasi elektronik melipatgandakan komunikasi, transportasi, produksi dan informasi. Disintegrasi negara-negara komunis yang mengakhiri perang Dingin. Adapun globalisasi telah merubah kehidupan masyarakat dunia secara umum, salah satu diantaranya adalah perkembangan teknologi informasi yang membawa dunia menjadi tanpa batas (borderless), khususnya dalam hal perekonomian/perdagangan, Menurut Giddens (1990): globalization involves the diffusion of ideas, practices and technologies. It is something more than internationalization and universalization. It isn't simply modernization or westernization. It is certainly isn't just the liberalization of markets.

\section{Republic of Technology}

Sapuan badai globalisasi melahirkan bahan material baru atau high-tech produk, dimana keinginan konsumen telah di standarisasi. Angin perubahan proletarianisasi komunikasi berjalan memasuki semua celah kehidupan. Komersialisasi tidak sebanding jika dibandingkan dengan kesuksesan Mc. Donald, Coca Cola. Tidak ada yang bisa menghentikan proses ini, sebagai struktur preferensi yang dihomogenkan.

\section{Vindication of the Model T}

Jika kekuatan sebuah perusahaan terhadap biaya dan penurunan harga turun lalu menekan kualitas maka standar yang diinginkan oleh konsumen adalah produk dengan standar dunia. Teori ini berpendapat, pada tahap dalam evolusi globalisasi, tidak peduli apa riset pasar konvensional dan bahkan akal sehat mungkin menunjukkan mengenai perbedaan nasional dan regional selera, preferensi, kebutuhan dan lembaga. Jepang membenarkan pendapat ini mereka tahu bahwa sukses di dunia adalah dengan menghomogenkan permintaan dan mencari peluang penjualan di segmen yang sama melintasi dunia dalam mencapai skala ekonomi yang diperlukan untuk bersaing.

\section{The Hedgehog Knows}

Rubah tahu banyak tentang banyak hal, tetapi landak mengetahui segala sesuatu tentang satu hal besar. Perusahaan multinasional tahu banyak tentang banyak negara besar dan berselera yang cocok beradaptasi dengan perbedaan seharusnya. Dengan rela menerima perbedaan nasional, tidak 
mempertanyakan kemungkinan transformasi mereka, tidak mengakui bagaimana dunia siap dan bersemangat untuk kepentingan modernitas, terutama saat harga yang tepat. Modus perusahaan multinasional akomodatif terhadap perbedaan nasional terlihat adalah abad pertengahan. Sebaliknya, perusahaan global tahu segala sesuatu tentang satu hal besar. Ia tahu tentang kebutuhan mutlak untuk menjadi kompetitif secara global maupun nasional dan berusaha terus untuk menurunkan harga dengan standarisasi apa yang menjual dan bagaimana hal itu beroperasi.

\section{Remaining Difference}

Preferensi budaya yang berbeda, selera dan standar nasional, dan lembaga bisnis sisa-sisa masa lalu. Beberapa warisan mati secara bertahap, yang lain makmur dan memperluas ke preferensi mainstream global. Banyak dari perbedaan ini di antara bangsa-bangsa untuk produk dan fitur mereka benar-benar mencerminkan akomodasi dan menghormati perusahaan multinasional untuk apa yang mereka yakini adalah tetap preferensi lokal.

\section{Economy of Scope}

Salah satu argumen yang menentang globalisasi mengatakan bahwa otomatisasi pabrik ukuran besar akan memungkinkan untuk mengubah produk dan fitur dengan cepat, tanpa menghentikan proses perakitan. Pabrik-pabrik ini di masa depan dapat menghasilkan saluran yang luas dari produk yang disesuaikan tanpa mengorbankan skala ekonomi yang berasal dari proses produksi dari barang yang distandarisasi.

Secara heuristika menyinggung soal globalisasi ini timbul banyaknya asumsi yang salah adalah marketing secara global, yang berarti memberikan pada konsumen apa yang mereka inginkan, sebaliknya tidak berusaha untuk mengerti apa yang mereka inginkan. Dalam sebuah tulisan yang sangat terkenal oleh Levitt dalam Borong (n.d.) yang beberapa kali diterbitkan ulang, dia mengatakan bahwa kegagalan usaha yang dilakukan oleh Hoover adalah pada pasar mesin cuci di Eropa Barat, yaitu biaya manufacturing yang tinggi tetapi tidak diikuti dengan penjualan yang baik, dan terlalu memperhatikan apa yang dikatakan oleh konsumen tanpa memperhatikan apa yang terjadi di pasaran, ide dari pemikiran Levitt untuk menjawab pertanyaan atas fitur apa yang konsumen inginkan yang membuat ia menjadi sangat terkenal. Selanjutnya Christensen, (1997) dari Harvard Business School menulis The innovator's Delemma, ia sependapat dengan Levitt bahwa perusahaan seringkali tergesagesa memberikan persis seperti apa yang konsumen ingin, perusahaan banyak membuang-buang uang untuk ini tanpa memikirkan fitur dan gunsi yang konsumen inginkan apakah sesuai untuk dibeli oleh para konsumen.

\section{Thomas Friedman "The World is Flat"}

Friedman (2005) menidentifikasikan dunia tanpa batas dan ciri-ciri ranah globalnya adalah: (1) runtuhnya tembok berlin (1989), yang juga menunjukan berakhirnya perang dingin sehingga mulai terjadinya perubahan dan terintegrasi perekonomian secara perlahan-lahan. Pada masa ini revolusi teknologi yang terjadi adalah mulai masuknya sistem operasi windows yang dibuat oleh Microsoft untuk dijadikan sebagai standar personal komputer, dan juga diikuti oleh IBM dengan membuat sebuah komputer yang khusus untuk digunakan secara personal. (2) Kelahirannya browser Nescape (1995), yang pertama kali dijual bebas seharga 28 dolar. Era ini merupakan permulaan website dan internet menjadi akar komunikasi yang mulai banyak digunakan. Era digital ini mulai banyak digunakan file, film, music, dan gambar dalam komunikasi elektronik ini. (3) Software komputer yang menjadikan terjadinya interaksi antara mesin dan manusia. Friedman mempercayai bahwa ketiga faktor di atas menjadi fondasi kolaborasi global. Bahasa SMTP (simple transfer protocol) dan HTMP (hypertext markup language) telah membawa kemudahan bagi orang untuk mentransmisikan dokumen ke semua komputer di dunia. Ia mengatakan bahwa ini adalah gerakan awal dimulainya satu orang dapat bekerja sama dengan yang lainnya tanpa harus berada di suatu tempat yang sama, dapat dilakukan di tempat yang berbeda. 
Selanjutnya bagi perusahaan adalah: (4) perusahaan yang melakukan sub kontrak atau outsourcing, merupakan salah satu langkah dalam menekan biaya operasional hingga menjadi sangat efektif. Proses ini dianggap yang paling mudah dan efektif dalam mendistribukan barang. Karena dalam sub kontrak ini juga dapat membagi antara jasa dan manufaktur. (5) Relokasi internal perusahaan atau offshoring merupakan salah satu cara dalam mengambil keuntungan pada biaya operasional. Bergabungnya China pada WTO adalah mengijinkan hal ini terjadi, maka negara-negara lain seperti Malaysia, Mexico, Brazil harus berkompetisi dalam bidang offshore ini dengan China. (6) Pengunggahan dalam sebuah komunitas dalam menjalankan sebuah projek, contohnya dalam open source. Ia mengatakan bahwa hal ini merupakan fenomena kekuatan yang paling mengganggu dari semuanya. (7) Supply-chaining pada pasokan ritel modern dengan mencontohkan Wal-Mart sebagai salah satu peruhaan yang menggunakan metode ini dalam penjualan, distribusi dan pengirimannya. (8) Insourcing digambarkan oleh Friedman dimana karyawan dalam melakukan layanan di luar pengiriman terhadap perusahaan lain. (9) In-forming yang dilakukan oleh google dan perusahaan mesin pencarian lagi. Ia mengatakan bahwa tidak pernah di dalam sejarah peradaban manusia memiliki kemampuan dalam mengakses informasi yang sangat banyak tentang berbagai hal. (10) The Steroid atau wireless, VOIP, dan sharing file dalam dunia internet. Mobile teknologi ini dapat dilakukan dimana saja dan kapan saja.

Selain sepuluh ciri-ciri the flat world yang digambarkan oleh Friedman, ia juga mengatakan adanya triple konvergensi yang terjadi sampai dengan tahun 2000. Adanya suatu multifungsi yang di kompakan ke dalam suatu alat (complementary) seperti email, mesin fax, mesin fotokopi merupakan salah satunya. Setelah kemunculan flatterners ini bisnis model yang baru yang berbasiskan inovasi seperti itu yang akan meraih sukses. Apabila flatteners berjalan sendirian, maka tidak akan memiliki pengaruh yang tinggi, tanpa digunakan oleh orang lain. Setelah runtuhnya tembok Berlin, negaranegara yang mengikuti model ekonomi seperti Uni Soviet termasuk India, China, rusia, dan negaranegara di Eropa, Amerika Latin, dan Asia Tengah mulai membuka ekonominya pada dunia. Pemainpemain baru ini bergabung dengan pasar global, konvergensi ini dinamakan konvergensi ketiga yang merupakan salah satu bentuk dari bagian penting perekonomian pada awal abad ke-21.

\section{Entrepreneurs dan Peluang dalam Globalisasi}

Dari sepuluh mitos tentang entrepreneur menurut Kuratko (2008), salah satunya adalah entreprneur adalah extreme risk taker .... gambler, resiko bagi seorang entreprenur adalah elemen utama dalam prosesnya. Persepsi umum tentang seorang entrepreneur adalah seorang orang yang tidak biasa. ini juga menimbulkan pandangan bahwa entrepreneur adalah penjudi, padahal situasi yang dihadapi entreprenuer sejati adalah moderat dan resiko telah dikalkulasikan dengan baik. Entrepreneur yang berhasil mereka telah melakukan persiapan yang tinggi dalam melakukan visi bisnisnya. Teori mengenai entrepreneurship yang dapat dibuktikan dan secara koherensi logis, contohnya dengan memperhatikan kondisi dan karakteristiknya maka akan membawa pada perusahaan dengan formasi baru, atau memberikan bimbingan normatif untuk menentukan pada suatu situasi khusus bahwa pada era milenium ini memerlukan suatu pemahaman pada situasi baru ini. Pada studi kontemporer konsep entrepreneurship yang muncul entrepreneurship adalah interdisipliner. yaitu mengandung berbagai pendekatan dalam memahaminya, dimana kita memerlukan adanya beragam teori untuk membentuk entrepreneur.

Dalam berbagai literatur mengenai entrepreneurship dikatakan bahwa seorang entrepreneur adalah orang yang berani mengambil resiko, dapat melihat peluang, inovatif, independent dan visioner. Sejak pertama kali diperkenalkan oleh Cantilon pada tahun 1775, perkembangan entrepreneurship hingga akhirnya pada tahun 2003 didefinisikan oleh komisi Eropa. 
Tabel 1 Time Line Entrepreneurship Definition

\begin{tabular}{|c|c|}
\hline Essence of definition & Publication \\
\hline $\begin{array}{l}\text { Entrepreneurs buy at certain prices in the present and sell at uncertain prices in } \\
\text { the future. The entrepreneur is a bearer of uncertainty. }\end{array}$ & (Cantillon, 1755/1931) \\
\hline Entrepreneurs are „pro-jectors . & (Defoe, 1887/2001) \\
\hline $\begin{array}{l}\text { Entrepreneurs attempt to predict and act upon change within markets. The } \\
\text { entrepreneur bears the uncertainty of market dynamics. }\end{array}$ & $\begin{array}{l}\text { (Knight, 1921) } \\
\text { (Knight 1942) }\end{array}$ \\
\hline $\begin{array}{l}\text { The entrepreneur is the person who maintains immunity from control of } \\
\text { rational bureaucratic knowledge. }\end{array}$ & (Weber, 1947) \\
\hline $\begin{array}{l}\text { The entrepreneur is the innovator who implements change within markets } \\
\text { through the carrying out of new combinations. These can take several forms: } \\
\text { The introduction of a new good or quality thereof, } \\
\text { The introduction of a new method of production, } \\
\text { The opening of a new market, } \\
\text { The conquest of a new source of supply of new materials or parts, and } \\
\text { The carrying out of the new organisation of any industry. }\end{array}$ & (Schumpeter, 1934) \\
\hline $\begin{array}{l}\text { The entrepreneur is always a speculator. He deals with the uncertain conditions } \\
\text { of the future. His success or failure depends on the correctness of his } \\
\text { anticipation of uncertain events. If he fails in his understanding of things to } \\
\text { come he is doomed... }\end{array}$ & (von Mises, 1949/1996) \\
\hline The entrepreneur is co-ordinator and arbitrageur. & (Walras, 1954) \\
\hline $\begin{array}{l}\text { Entrepreneurial activity involves identifying opportunities within the economic } \\
\text { system. }\end{array}$ & (Penrose, 1959/1980) \\
\hline $\begin{array}{l}\text { The entrepreneur recognises and acts upon profit opportunities, essentially an } \\
\text { arbitrageur. }\end{array}$ & (Kirzner, 1973) \\
\hline $\begin{array}{l}\text { Entrepreneurship is the act of innovation involving endowing existing } \\
\text { resources with new wealth-producing capacity. }\end{array}$ & (Drucker, 1985) \\
\hline $\begin{array}{l}\text { The essential act of entrepreneurship is new entry. New entry can be } \\
\text { accomplished by entering new or established markets with new or existing } \\
\text { goods or services. New entry is the act of launching a new venture, either by a } \\
\text { start-up firm, through an existing firm, or via ,internal corporate venturing . }\end{array}$ & (Lumpkin \& Dess,1996) \\
\hline $\begin{array}{l}\text { The field of entrepreneurship involves the study of sources of opportunities; the } \\
\text { processes of discovery, evaluation, and exploitation of opportunities; and the } \\
\text { set of individuals who discover, evaluate, and exploit them. }\end{array}$ & (Shane \& Venkataraman, 2000) \\
\hline $\begin{array}{l}\text { Entrepreneurship is a context dependent social process through which } \\
\text { individuals and teams create wealth by bringing together unique packages of } \\
\text { resources to exploit marketplace opportunities. }\end{array}$ & (Ireland, Hitt, \& Sirmon, 2003) \\
\hline $\begin{array}{l}\text { Entrepreneurship is the mindset and process to create and develop economic } \\
\text { activity by blending risk-taking, creativity and/or innovation with sound } \\
\text { management, within a new or an existing organisation. }\end{array}$ & $\begin{array}{l}\text { (Commission of the European } \\
\text { Communities, 2003) }\end{array}$ \\
\hline
\end{tabular}

Sumber: Ahmad \& Seymour (2008)

Negara-negara anggota ASEAN telah membuat sebuah komitmen dalam peningkatan perekonomian antar negara-negara anggotanya dan persiapan menuju ekonomi global. Tujuannya adalah untuk komitmen jangka panjang pada bidang keamanan, ekonomi, sosial budaya, dan upaya penanganan perubahan iklim dunia. Salah satu bentuk kerjasama yang dilakukan adalah AFTA (ASEAN Free Trade Aggreement), tetapi kenyataannya disparitas ekonomi sesama anggota masih terjadi walaupun di balik itu terdapat kesempatan tidak hanya ekonomi tetapi sosial, budaya dan pendidikan. Dalam mempercepat proses transformasi ekonomi dan pendidikan khususnya yang berhubungan dengan entrepreneurship lintas negara menjadi sangat penting (Adlrich \& Zimmer, 1986).

Pentingnya akses globalisasi bagi seorang entrepreneurs adalah memanfaatkan peluang dan penggalinya secara positif, menurut Latif \& Ghazali (2010) identifikasi peluang iklim globalisasi adalah: (1) akses atas kecepatan telekomunikasi; (2) akses kecepatan dan murahnya transportasi, 
contohnya maskapai Air Asia; (3) infrastruktur keuangan yang lebih baik; (4) peluang riset seperti agro industri dan bentuk inovasi lainnya; (5) infrastruktur administratif yang lebih baik; (6) munculnya inovasi baru pada bentuk pengajaran khususnya pada lembaga pendidikan.

Dengan memperkenalkan metode produksi baru, membuka pasar baru dengan melalui inovasi merupakan salah satu kekuatan inti dari seorang entrepreneur. Entrepreneurship didefinisikan oleh banyak peneliti sebagai katalisator ekonomi, sistesis pengetahuan tentang entrepreneurship menjadi demikian penting mengingat dampaknya atas pertumbuhan ekonomi Kukoc \& Regan (2008). Negaranegara di Eropa telah berpengalaman dalam research and development (R\&D) tidak berpengaaman dalam mendorong pertumbuhan ekonomi dalam dua dekade ini. Dalam beberapa studi empiris mempercayai bahwa hubungan positif antara pengeluaran R\&D dengn pertumbuhan ekonomi terjadi sebuah missing link, dan dipercayai bahwa missing link tersebut adalah entrepreneur Shank and Zheng PC (Jaumote \& Pain, 2006).

\section{Paradigma Internasionalisasi dan Globalisasi}

Kosepsi tentang internasionalisasi dan globalisasi berdasarkan hasil penelusuran kepustakaan yang didapat ternyata merupakan dua konsep yang berbeda dalam keluasan jangkauannya. Globalisasi, menurut Poerwadarminta (2007) dalam Kamus Besar Bahasa Indonesia, adalah proses masuknya ke ruang lingkup dunia atau global, sedangkan Internasionalisasi adalah yang berkaitan dengan bangsabangsa. Internasionalisasi sifatnya lebih sempit atau divergen jika dibandingkan dengan global yang bersifat konvergen dengan adanya gerakan yang homogen dari masyarakat secara umum menuju satu kesatuan persamaan persepsi. Sugiharto (2008) berpendapat bahwa dalam situasi millennium ketiga ini telah terjadi reaksi atau mobilisasi planeter masyarakat dunia dimulai sejak terjadinya tsunami Aceh tahun 2004, badai Katrina di Mississippi di Amerika Serikat tahun 2005 dan gempa bumi di Chili 2010

Pemahaman akan konsepsi atas perbedaan antara internasionalisasi dan globalisasi merupakan hal penting yang harus dimengerti oleh para manager perusahaan atau bagi seorang entrepreneur dalam menjalankan usahanya dan menjawab pasarnya apakah internasional atau global? Ini dimaksudkan pada alasan untuk mengukur besarnya dan ekspansi pasar yang akan dilakukan. Bagaimana mereka dalam mengintrepretasikan ekonomi yang saling tergantung satu sama lainnya antar negara. Ide provokatif awal yang dikeluarkan oleh Levitt merupakan sebuah gagasan dan konsep yang digambarkan untuk peningkatan ekonomi lintas batas tetapi menggambarkan perubahan karakter di dalamnya, dimana mereka mengubah masyarakat dalam melakukan transaksi perdagangan atau usaha.

Pusat argumentasinya adalah pada komunikasi dan teknologi yang meggerakan masyarakat ke arah modernisasi, mengarahkan pada tujuan yang sama, pengentasan kemiskinan, dan perluasan daya beli. Globalisasi berimplikasi aktivitas kegiatan ekonomi tanpa adanya batas-batas nasional, sementara internasionalisasi adalah peningkatan jumlah transaksi melintasi batas-batas negara, dimana masih adanya control penuh dari pemerintah dimana adanya pilihan untuk mau atau tidak mau untuk membuka diri. Perusahaan global beruperasi pada ekonomi global sedangkan perusahaan multinasional dan perusahaan global tidak sama. Perusahaan multinasional memproduksi barang untuk pasar nasional, sedangkan perusahaan global memproduksi barang dengan standarisasi untuk seluruh market.

Keterbukaan akses informasi secara global telah membuka peluang yang berpotensi pasar tinggi, salah satu peluang yang dianggap memiliki potensi adalah di bidang e-commerce. Kuratko (2008), bentuk-bentuknya adalah (1) the electronic commerce (e-commerce): marketing, promosi, jual beli barang dan jasa secara elektronik. Khususnya internet telah membentuk gelombang baru dalams transaksi bisnis. Selanjutnya (2) e-commerce model dalam penggunaan internet; e-tailing (virtual store 
fronts), electronic data interchange (EDI), e-mail and computer faxing, business-to-business (B2B) buying and selling, ensuring the security of data transactions.

Momentum dan kerangka lingkungan baru ini merupakan peluang bagi setiap usaha yang baru didirikan untuk dapat merebut pangsa pasar dunia secepat mungkin. Karena lingkungannya yang dinamis, maka terbentuk sebuah situasi unik di mana perusahaan dapat secara efektif memanfaatkan sumber daya internal dan kemampuan mereka. Selama beberapa dekade terakhir abad ke-20, kita telah melihat kemajuan teknologi dan integrasi ekonomi global. Ekonomi Baru ini yang membuat perbedaan signifikan diantara semua industri di seluruh dunia. Perusahaan lama dan dan perusahaan baru telah menghasilkan keuntungan dari situasi ini, dengan cepat merubah sebuah perusahaan menjadi raksasa seperti Microsoft dan Google. Menurut Drucker (1992), penciptaan usaha baru startup di Amerika Serikat setiap tahun telah meningkat menjadi 600 ribu, sejumlah tujuh kali lebih besar dari pada perusahaan yang didirikan selama 1950/60. Di Taiwan fenomena yang sama juga terjadi, contohnya adalah fenomena Quanta Computer dan HonHai/Foxconn, yang didirikan oleh Barry Lam dan Terry T.M Gou.

\section{PENUTUP}

Pemikiran terhadap konsteks global adalah sebuah lingkungan yang homogen tetapi sukar untuk dimasuki, standarisasi atas produk dunia sulit untuk diikuti dengan mudah terutama oleh negaranegara ketiga dikarenakan standar nasional masing-masing negara yang berbeda-beda. Catatan penting mengenai iklim global ini selain membentuk lingkungan perusahaan dalam berkompetisi global secara head to head juga membentuk kompetisi man to man. Berbagai tulisan ekonomi tentang strategi percepatan dalam memanfaatkan situasi global bagi sebuah perusahaan lama dan perusaahaan baru (startup) di prediksi dapat berkembang dengan cepat. Bagian yang sulit adalah bagaimana mempersiapkan diri dengan berbagai kemampuan dan strategi dalam mengikuti standar global ini. Dimana selama ini adanya gap standarisasi yang berbeda-beda dalam setiap negara. Kenyataannya banyaknya perusahaan global berasal dari negara-negara barat, yang memiliki implikasi di luar ekonomi saja yaitu dampak sosial, berbagai aksi-aksi anti barat banyak dilakukan oleh para aktivis garis keras (teroris). Dalam sebuah pidato pencalonan presiden Barrack Obama mengatakan bahwa salah satu pemicu lahirnya terorisme adalah kemiskinan oleh sebab itu salah satu gagasan Obama adalah dengan menjalin bekerja sama antar negara di bidang ekonomi dan membuka lapangan pekerjaan yang dapat menyerap penggangguran di Amerika Serikat. Evolusi kondisi ekonomi ini menyisakan berbagai tantangan yang perlu dijawab oleh orang-orang luar biasa (entrepreneur) yang mampu melihat peluang di dalamnya. Konvergensi yang dinyatakan oleh Levitt dan Friedman mengenai revolusi teknologi bukan menjadi hal yang mudah untuk diikuti bagi negara-negara ketiga seperti Indonesia, hal ini terbukti masih dapat dihitung perusahaan Indonesia yang mampu manggung dalam tingkat global. Tantangan perubahan ini memerlukan sebuah paradigma berpikir dan strategi baru dalam mempersiapkan diri maupun perusahaan untuk memasuki pasar global.

\section{DAFTAR PUSTAKA}

Ahmad, N., \& Seymour, R. G. (2008). Defining entrepreneurial activity: definitions supporting frameworks for data collection, OECD Statistics directorate. Working Paper STD/DOC(2008). Diunduh pada Februari 2011, dari www.oecd.org/dataoecd/2/62/39651330.pdf

Aidrich, H., \& Zimmer, C. (1986). Entrepreneurship through social network. In S. D. Similor (Ed.), The art and science of entrepreneurship. Cambridge MA: Ballinga. 
Borong, R. P. (n.d.). Globalisasi. Diakses pada Juni 2008, dari http://www.artikel.sabda.org/globalisasi

Christensen, C. M. (1997). The innovator's dilemma: when new technologies cause great firms to fail. Boston, Massachusset: Harvard Business School Press.

Cline, A. (n.d.). The economics of society and religion: Karl Marx's economic theories. Diakses pada Februari 2011, dari http://atheism.about.com/od/philosophyofreligion/a/marx_3.htm

Drucker, P. (1992), Managing for the future, New York: Truman Talley/ E.P. Dutton.

Friedman, T. (2005). The World is Flat: a brief history of the twentieth-first century. Farrar, Straus and Giroux.

Giddens, A. (1991). The consequences of modernity. Stanford: Stanford University Press.

Latif, A. A. A. B., \& Ghazali, A. (2010). Opportunities for Cross Boarder Entrepreneurship Education in ASEAN Region. Proceeding of The Second Indonesia International Conference on innovation, Entrepreneurship and Small Business, Developing Technopreneurship and Entrepreneurial Small Business: A Key to Sustainable Future, July 11-15, 2010, SMB-ITB, UMN, Serpong, Banten, Indonesia, 2010.

Jaumotte, F., \& Pain, N. (2006). From ideas to development: the determinants of R\&D and patenting. OECD Economics Department Working Paper, No. 457, 2006.

Kardoyo, H. (2008). Generation "Y" will challenge the business world traditions. The Jakarta Post. Diakses pada Februari 2011, dari http://www.thejakartapost.com/news/2008/10/03/generation\%E2\%80\%9Cy\%E2\%80\%9D-will-challenge-business-world-traditions.html

Kuhn, T. S. (1970). The structure of scientific revolutions (2nd ed.). Chicago: University of Chicago Press.

Kukoc, K., \& Regan, D. (2008). Measuring entrepreneurship, treasury economic roundup. Diunduh pada Februari 2011, dari www.treasury.gov.au/documents/1352/PDF/02_Entrepreneurship.pdf,

Kuratko, D. F., (2008). Entrepreneurship: Theory, Process, and Practice, $8^{\text {th }}$ Ed.Ohio: Southwestern Publishing

Poerwadarminta, W. J. S. (2007). Kamus umum Bahasa Indonesia. Jakarta: Balai Pustaka.

Schumpeter, J. A. (1934). The theory of economic development: an inquiry into profits, capital, credit, interest, and the business cycle. Cambridge, MA: Harvard University Press.

Sugiharto, B. (2008). Humanisme dan humaniora, relevansinya bagi pendidikan. Yogyakarta dan Bandung: Jalasutra. 